\title{
Character is Fate: Henchard's Rise and Fall in The Mayor of Casterbridge by Thomas Hardy
}

\section{Karakter Kaderdir: Thomas Hardy'nin romanı The Mayor of Casterbridge'de Henchard'ın Yükselişi ve Düşüşü}

\section{Ercan GÜROVA*}

\begin{abstract}
Thomas Hardy, regarded as the final novelist of the Victorian Era, has certain characteristics which distinguish him from his contemporaries. One of these is "the phenomenon of coincidence". It does the fictitious characters harm rather than a favor. The density of disasters in his novels strengthens the thesis that Thomas Hardy looks at life from the perspective of a tragedy author as a representative of naturalism. Hardy's pessimistic attitude is perhaps not so difficult to understand if we remember that he was living in an age of sudden scientific development and a rapid changes to the old, accepted values. This article examines how and to what extent Michael Henchard in The Mayor of Casterbridge can be considered a person who experiences misfortunes and is doomed to fail. It will also be questioned whether or not he is the victim of the flaws in his personality and therefore has a tragic end. It will be concluded that what prepares the end of Michael Henchard is not the dark games of destiny but the dark powers in the personality of Henchard that devastated him.
\end{abstract}

Keywords: Hardy, Victorian, Coincidence, Misfortunes

$\ddot{O}_{z}:$ Viktorya dönemi İngilteresi'nin en son romancısı olarak kabul edilen Thomas Hardy'i çağdaşlarından ayıran belirli özellikler vardır. Bunlardan biri de "rastlantı olgusu"dur. Bu olgu kurgu karakterlere iyilikten ziyade kötülükte bulunur. Romanlarındaki felaketlerin yoğunluğu naturalizmin bir temsilcisi olarak Hardy'nin yaşama bir trajedi yazarının bakış açısıyla baktığı savını güçlendirir. Kendisinin ani bilimsel değişikliklerin ve eski, kabul görmüş değerlerde hızlı bir değişimin olduğu bir çağda yaşadığını hatırlarsak Hardy'nin karamsar tavrını anlamak belki de o kadar zor değildir. Bu makale The Mayor of Casterbridge romanında Michael Henchard'ın nasıl ve ne ölçüde talihsizlikler yaşayan ve başarısızlığa uğramaya mahkum biri olduğunu ve kişiliğindeki kusurların mağduru olup olmadığını ve dolayısıyla trajik bir sonla karşılaşmasını incelemektedir. Romanın başlığı ve altbaşlığı da mercek altına alınacak ve romana dair ne önerdiği tartışılacaktır. Romanın ana karakteri Michael Henchard'ın trajik sonunu getiren şeylerin kaderin bir oyunu veya talihsizliğin bir sonucu değil kendi karakterindeki kusurlar olduğu ve bu yüzden yıkıma uğradığı sonucuna varılmaktadır.

Anahtar sözcükler: Hardy, Viktoryen, Rastlantı, Talihsizlikler

It wouldn't be wrong to say that the literary genre which left its mark on the nineteenth century, specifically in the Victorian Era, was the novel. In addition to the fact that it raised great names such as Dickens, Thackery, Eliot, Hardy and the Bronte Sisters, various social, economic, scientific and philosophical arguments of the era added depth, novelty and diversity to the works written as a result of unprecedented change, transformation and turbulence. As stated in

\footnotetext{
*Instructor, Ankara University, School of Foreign Languages, Ankara. ercangurova@hotmail.com
} 
the essay by John Stuart Mill entitled, "The Spirit of the Age", "it is an age of transition" (Mill $2,2007)$. The change in organizations, the transformation of occupational areas, the changes in the welfare distribution, the reaction of the working class, the growth of the middle-class and reforms were the most remarkable results of this age of transition. It is unthinkable that the novelists of this era would remain unconcerned by these developments.

The poet and the novelist Thomas Hardy who has been regarded as the final novelist of the Victorian Era wrote more than forty stories, approximately nine hundred poems, an epic drama named The Dynasts with one hundred thirty scenes, a theater play named The Famous Tragedy of the Queen of Cornwell and fourteen novels in his lifetime. Different from the well-known authors of England of the time, he neither went to a distinguished university such as Oxford or Cambridge, nor did he receive a proper education. He was apprenticed to an architect when he was 16 years old but he was deeply interested in literature. He was an autodidact to the core. In other words, he knew how to self-educate himself. He continuously read and learned Latin and ancient Greek. When he was thirty-three years old, together with the publication of Far From the Madding Crowd in 1873, which was his first novel to gather much public attention and was regarded as a masterpiece by some, Hardy gave up architecture and dedicated himself to literature (Millgate 2004, 7-8).

One of Hardy's characteristics was that almost all his novels are set within an area covering south and southeastern England termed Wessex. This led to him to being described as a regional novelist. The second is that the main characters of his novels are the males and females of country origin, as the rural population and their lives are generally addressed rather than wealthy persons, high society women, artists, scientists and intelligentsia as mostly depicted in the other novels of the Victorian Era. His works are peopled by characters such as hay-binders, crofters and tinkers; characters all drawn from his own first hand observation and experience. Another distinctive characteristic of Hardy is that he takes the view that reality is not art. According to him, "Art is disproportioning of realities, to show more clearly the features that matter in these realities" (Lothe 1999, 114). Also, he mentions the necessity of sticking to realism when dealing with the persons in a novel, rather than the incidents by stating that, "it is not improbabilities of incident but improbabilities of character that matter" (My translation) (Urgan 2003, 1310). Yet another distinguishing characteristic of Hardy from his contemporaries is his approach to religion. He completely moved away from religion after he read the works of authors such as Charles Darwin, Herbert Spencer and John Stuart Mill. When he was fifty, he said; "I have been looking for God for fifty years, and I think that if he had ever existed I should have discovered him" and he maintained this opinion during the First World War (Schweik 1966, 54). Despite all, Hardy still believed in the existence of a power. This power was sometimes an immanent will and sometimes the president of immortal. This power did not bear a resemblance to the merciful God of traditional religion. This power was rather a blind power aiming to do neither a favor nor an evil and completely remaining unresponsive to them; behaving inconceivably and unconsciously in regard to coincidence. Hardy denominated this power sometimes as "Chance" and sometimes as "Hap" or "Crass Casualty" in his poetry (Urgan 2003, 1312).

\section{Thomas Hardy and His Novel Style}

In the preface to Tess of the d'Urbervilles, Hardy writes; "a novel is an impression, not an argument" (Hardy 2000, xx). In the preface to Jude the Obscure, he continues as follows: "it is simply an endeavor to give shape and coherence to a series of seemings, or general impressions, the question of their consistency or their discordance...being regarded as not of the 
first moment" (Hardy 2002, xiii). When Virginia Woolf mentions the novels of Hardy in her work entitled The Common Reader Series Second, she describes Hardy's novel style as follows: "it is a means of giving truthful if harsh and violent impressions of the lives of men and women" (Woolf 1935, 141). She also refers to Hardy's inclination to naturalism saying that he is a meticulous and skillful observer of nature but he feels the existence of a soul in nature which lends support to the destinies of people or a soul which ridicules people or only watches them listlessly (Woolf 1935, 141). After adding that the author has a very strong and sarcastic imagination, she claims that Hardy is unable to control the characters that he created. She criticizes him for using coincidences in an extraordinary and melodramatic way and regards this as a frailty. She, however, dignifies Hardy with being "the biggest tragic author among the English novelists" as his superior and distinctive characteristic (Woolf 1935, 145).

The phenomenon of coincidence that is frequently seen in the novels of Hardy does the fictitious characters harm rather than favor. For example; in The Mayor of Casterbridge, Henchard thinks that the harvest will be bad and buys a substantial amount of corn but the prices decline due to good weather conditions and Henchard makes a loss. In another example; in The Return of the Native, Mrs. Yeobright who goes to the house of her son in order to make peace cannot see Clyme and also a snake bites her. Therefore, she dies without making peace with her son. Eustacia delivers her letter to somebody in order to post it to Clyme but the man forgets to post the letter. In Tess of the D'Urbervilles, Tess writes Angel a letter in which she confesses her past to Angel with whom she is about to marry, but the letter that Tess has slipped under the door, is stuck beneath the carpet; Angel did not see that letter.

Some critics such as Lord David Cecil and Edwin Muir have alleged that the dark and mysterious forces of the universe were responsible for the disasters which happen to the characters in the novels of Hardy (Urgan 2003, 1373). Even if there are tragic cases at which the misfortunes of people play a role, explaining these only by means of these dark forces would be an oversimplification. In fact, Hardy identifies destiny with the main character's personality in The Mayor of Casterbridge by quoting from the $18^{\text {th }} \mathrm{c}$. German author Novalis: "Character is fate" (Hardy 2008, 107). In other words, he claims that character shapes the destiny of a person. Hardy advises that a person should resist his/her destiny instead of consenting to it. Commenting on Hardy's novels, Woolf says: "It's not destiny but your own weakness that is against you" (Woolf 1935, 142). To illustrate, Henchard could not have sold his wife and daughter and could not have lied to Elizabeth-Jane in The Mayor of Casterbridge. In Tess of the D'Urbervilles, Tess could have acted more wisely and could not have fallen into the trap of Alec D'Urbelville. Angel Care could have been more thoughtful and could have forgiven Tess. In Jude the Obscure, the main character could not have been carried away with the sexual attraction of a vulgar girl like Arabella. In Far From the Madding Crowd, Bathsheba could not have lost her heart to a womanizer like sergeant Troy. These characters would have acted differently if they had had a stronger personality.

The density of disasters in his novels strengthens the thesis that Thomas Hardy looks at life from the perspective of an author of tragedy. Although he introduces himself as "melioristic" rather than pessimistic, in other words he believes that the people may make the world better through their own efforts, there are characteristics resembling the Greek tragedies in his masterpieces named "The Tragic Novels," in The Return of the Native, The Mayor of Casterbridge, Tess of the D'Urbervilles and Jude the Obscure. For example; the ploughman Henchard transforms into a tragic king in The Mayor of Casterbridge and the country girl Tess transforms into a tragic queen in Tess of the D'Urbervilles. His novel Under the Greenwood Tree is his 
only famous work which is free from gloom and tragedy. Regarding the relationship between Hardy's novels and tragedy, in his essay "Art and Aesthetics" Norman Page states that "The Mayor of Casterbridge is by general consent one of the finest of his mature works and impressive testimony to his achievement in making the novel a vehicle for tragedy" (Page 43, 1999). Later, Page exemplifies the rich allusions to the Bible, the classics (including Greek and Roman mythology and history), Shakespeare and other English writers such as Defoe, Gray, Scott and Shelley, a few French and German writers, as well as folk beliefs and popular songs (Page 1999, 43).

Hardy's pessimistic attitude is perhaps not so difficult to understand if we remember that he was living in an age of sudden scientific development and a rapid change to the old, accepted values. Darwin had published The Origin of Species and its arguments were being widely discussed by people who had formerly believed in the teachings of the Bible. The developments in science and technology had also permanent influence upon Hardy's loss of faith and his doctrine of personal fate, or law of life.

This article examines how and to what extent Michael Henchard in The Mayor of Casterbridge can be considered a person who experiences misfortunes and is doomed to fail. It will also be questioned whether or not he is the victim of the flaws in his personality and therefore is a tragic character. There will also be a focus on the names of the title and subtitle of the novel and what they suggest in accordance with the story in the book.

\section{The Name of the Novel: The Mayor of Casterbridge}

There may be various reasons why the name of novel that Hardy published in 1886 is "The Mayor of Casterbridge", not Michael Henchard, although Michael Henchard is at the center of it. In the introduction to the book "The Mayor of Casterbridge" that Julian Wolfrey edited, it is stated that this title refers to a public constructed identity which is not personal and makes reference to a social position (Wolfreys 2004, 2). In his article entitled, "The Mayor of Casterbridge: The Fate of Michael Henchard's Character", Simon Gatrell mentions a similar reason but explains this within the context of a tragedy:

Why is it The Mayor of Casterbridge, not Michael Henchard? Why is Henchard's function more important than his name? The force of this question is intensified when it is remembered that he is mayor for less than half of the novel. A partial reason for the choice is probably to be found in one aspect of the novel's supporting structure of reference and allusion-classical and medieval theories of tragedy which demand that the tragic hero shall be a man of high status, for whom the wheel of fortune will turn downwards...to have been mayor provides sufficient social status for the operation of the rules of tragedy in Henchard's rapid and inexorable decline from that status and what it implies (49).

The novel The Life and Death of the Mayor of Casterbridge is, as the title suggests, an account of the instabilities, frustrations, successes and failures of a particular man. The writer introduces us to various characters in addition to Henchard but the primary concern throughout the novel is Henchard himself. The presence of other characters is necessary to unfold the plot and for Henchard's thoughts and actions. Yet it is the hay and corn merchant, Michael Henchard, who is really the subject of the author's and the reader's scrutiny. The struggles and misfortunes of Michael Henchard are set out in complete detail. 


\section{The Subtitle of the Novel: A Story of a Man of Character}

In his work named How to Read Literature, the famous Marxist critic, Terry Eagleton states that the word "character" is derived from the word kharakter (engraved mark) used in ancient Greece to leave a distinctive mark and then, it has taken on the meaning of a feature specific to a particular individual that we may regard as the signature of a person. Starting from this point, it would not be wrong to say that the word "character" refers to the sum of mental and moral qualities of an individual $(2013,48)$. In order to resolve the meaning that Hardy assigned to the word "character" in choosing this word in the subtitle of his novel, we should review the work, On Liberty by John Stuart Mill which we know Hardy read and was impressed by in that period. Mill mentions the significance of a person who has strong emotions, passions and urges:

To a certain extent it is admitted that our understanding should be our own: but there is not the same willingness to admit that our desires and impulses should be our own likewise; or that to possess impulses of our own, and of any strength, is anything but a peril and a snare. Yet desires and impulses are as much a part of a perfect human being, as beliefs and restraints; and strong impulses are only perilous when not properly balanced; when one set of aims and inclinations is developed into strength, while others, which ought to coexist with them, remain weak and inactive. It is not because men's desires are strong that they act ill; it is because their consciences are weak (56).

According to Mill, the human who has strong passions and impulses is a good person as long as the balance has been established between the emotions/passions and conscious/moral compass of a person. This balance is not available for Henchard, the main character of The Mayor Casterbridge. As his quick-tempered nature, pride and his impulsive acting without thinking through the consequence of anything have not been balanced by his conscience at the critical moments of his life; the consequence has always been destructive for himself and the people around him. To illustrate; when he auctions off his wife and daughter, attempts to behave against the rules when the royal family comes to the town and when he tries to kill Farfrae in the hayloft, he has done all these under the influence of alcohol. But desiring to drink alcohol is his preference and his irresponsibility shows how selfish and ignoble he can act. Moreover, by drinking alcohol, he enters under the command of his impulses.

In his work named On Liberty, Mill relates these strong impulses to a kind of energy. $\mathrm{He}$ reminds that good things may also occur out of this energy, but this energy may transform into bad as well (Mill 2001, 55). He states that the ones whose impulses are strong and alive may also proceed on the way of love and success. Henchard's advancing to the mayorship and gaining reputation in the town compared to his penniless condition at the beginning can be given as examples for the transformation of impulses into success. Finally, Mill explains what he means by the word "character" as follows:

A person whose desires and impulses are his own - are the expressions of his own nature, as it has been developed and modified by his own culture - is said to have a character. One whose desires and impulses are not his own, has no character, no more than a steam engine has a character. If, in addition to being his own, his impulses are strong, and are under the government of a strong will, he has an energetic character (56). 
Depending on the definition of Mill, we may say that Henchard has an energetic character, but it is hard to say that the strong impulses of Henchard are in conformity with his conscience/ moral compass. This character structure will prepare for the tragic end and the fall of Henchard.

\section{Michael Henchard as a Character}

In his article titled "The Fate of Micheal Henchard's Character", Simon Gatrell identifies Henchard as "proud, fiery, driven by imperious desires, uncaring of consequences, ruthlessly honest but destructive of himself and others around him" (Gatrell 2000, 55). In his article "Vision and Viewpoint in the Mayor of Casterbridge", Robert Kiely makes a comment on the character of Henchard, "He is not articulate enough to be Shakespearian, not sophisticated enough to be Byronic, not vicious enough to be a true descendant of Heathcliff" (Kiely 1968, 190). In fact, Henchard is not worse than the characters in the other novels of Hardy. Having a quick temper, being fond of alcohol and auctioning off his wife and daughter are his prominent aspects and they can be considered as the starting point of the disasters in the novel. As the novel progresses, some other features of Henchard start to attract our attention. Kiely expresses these features as follows:

Henchard's knowledge of himself is so rigid and imperfect, his understanding of others is limited to a simple dichotomy of identification or opposition. He will not tolerate natural multiplicity in himself and therefore cannot apprehend it in anyone else. When Farfrae begins to show signs of potency and initiative, Henchard feels betrayed because it had been inconceivable that a man so different in other ways could be like him in this (191).

All these do not make Henchard a "foolish" or "wooden" person. The real reason why he has difficulty in keeping pace with the changes imposed by life is his pride and rigidity. The failure and pettiness are the things that he always abstains from facing.

\section{Henchard vs Farfrae: an Example of Dichotomy}

The contrasts between Henchard who is at the focal point of the novel and Farfraea with whom he meets while he performs the mayorship and then he feels sympathy and employs, draw the reader's attention. Readers witness the fall of Henchard to the extent that Farfrae rises in the novel. Donald Farfrae was unemployed when he comes to Casterbridge but he has been well educated unlike Henchard. While Henchard is a middle-aged, sulky and imperious person, Farfrae is a young, debonair, flexible and tolerant. He does not get carried away with his emotions like Henchard; in other words, he behaves rationally. But he has a sensitive side as well. He inebriates everybody by singing the folk songs of his hometown in Scotland with his nice voice. When he begins to work with Henchard, the contrasts between them start to draw our attention more. For example; Farfrae is more reasonable, thoughtful and tolerant while Henchard behaves extremely rigidly and inconsiderate towards an employee who does not come to work on time. When both started to organize meetings individually, everybody goes to the entertainment that Farfrae has organized in a big tent while the outdoor entertainment organized by Henchard was cancelled due to the rain. When they fall out because of his stepdaughter Elizabeth-Jane, Farfrae sets up his own business of grain and day by day, he earns much more money while Henchard who visits a fortune teller for the weather for the harvesting, takes wrong decisions and makes untimely sales, goes bankrupt. Moreover, Farfrae brings the first agricultural machines to Casterbridge. While Henchard is applying old-fashioned work methods, Farfrae has adopted new commercial methods. At the end, Henchard who has been 
driven into complete poverty enters the service of Farfrae and he works like a farmhand in the storehouses which had previously been his own properties. In parallel with this fall of Henchard, Farfrae becomes the mayor of Casterbridge following his fortune and his marriage with Elizabeth-Jane.

\section{Cycles of Hope and Catastrophe in Henchard's Life}

Throughout the novel, there is a cyclical arrangement at which the hopes of Henchard are raised and everything has started to get better but which is the then followed by returns or reversal and falls. In these cycles, the hopeful moments and developments for Henchard have resulted in a disaster due to his hot tempered and rigid nature and his impulses that he cannot control. In the following cycle, the expectations, success, and happiness of Henchard also decrease.

After Henchard has auctioned off his wife and daughter, a new period starts with his oath on not touching alcohol for 21 years. 19 years later, we see Henchard as the mayor of Casterbridge town and a rich tradesman. In other words, he has progressed in terms of both welfare and social position. Then, he takes the personal assistance and commercial support of Farfrae. He does not turn his lost wife and daughter adrift and looks after them when they show up one day. We may suppose that Henchard has really changed, along with all these things but in fact, he is still the same in terms of various aspects.

When he attempts to punish his worker, Abel Whittle, the fall in the first cycle becomes apparent along with his hot-tempered and disproportionate reactions which do not tolerate weakness. His unfair and vehement attitudes are reminded as the dominant cases of his personality. As his rigidity and mercilessness increase, his wealth decreases. In addition to the fact that he has fallen out with Farfrae, he starts to say things such as "grind him into the ground" or "starve him out" about the career of his friend (Hardy 2008, 199). Turning his back on Farfrae is followed by the frigidity, negligence and skepticism that he shows towards Elizabeth-Jane. He progressively moves away from Elizabeth-Jane when he finds out that he is not her biological father and he begins to detest her. When he is rejected by Lucetta, he threatens the woman by disclosing her secret affairs. At this point, the furmity seller woman who may be regarded as the nemesis of Henchard comes on the stage. When she is brought to court due to a crime, she comes across Henchard in the capacity of the mayor of the town and she claims that such a person who has auctioned off his wife and daughter cannot be in the position of judging her. Therefore, another contribution was made to the fall of Henchard. In such a case, Henchard feels the illusion that a secret power or a supernatural power works to his detriment instead of realizing the disasters which have occurred were due to his inconsiderate and insensible wrong decisions: "Henchard, like all his kind, was superstitious, and he could not help thinking that the concatenation of events this evening had produced was the scheme of some sinister intelligence bent on pushing him" (Hardy 2008, 118).

The second cycle starts with a hope again. He shows his honesty by accepting the accusations of furmity woman and leaving the hall of the court. He rises in the scene where he admits that he has behaved unfairly against Farfrae: "I- sometimes think I've wronged 'ee!" (Hardy 2008, 210). He makes his peace with Elizabeth-Jane again. An improvement is seen at the situation of Henchard.

While Hardy convinces us that Henchard has approached maturity, integrity and good sense, we witness the descending action for the second time with an immediate reversal. When the 21 year- period of alcohol abstinence has expired, a new "era of recklessness" starts. His hidden sinister characteristics are shown again. Hate and violence are some of these characteristics. For 
example; he mentions the letters of Lucetta even though he has not given her name and uses this as a threat.

Henchard brings the issues to the point of violence twice and in both cases, he waives from these himself anywise. In the first case, he wants to defy Farfrae and wants to welcome the Royal visitor himself and he encounters the reaction and intervention of Farfrae. In the second case, he attacks Farfrae in the hayloft: "Now', said Henchard between his gasps, 'this is the end of what you begin this morning. Your life is in my hands'. 'Then, take it, take it!' said Farfrae. 'Ye've wished too long enough" (Hardy 2008, 254). As Henchard has been affected from the reproachful accusations of Farfrae, he cannot continue his actions and then, he regrets for the things he has done. Then, he vainly attempts to save the life of Lucetta but he has difficulty in persuading Farfrae.

In fact, Henchard is responsible for the developments which in a sense bring about the death of Lucetta. He has become the starter of developments which have led to the instantaneous death of Lucetta by not destroying her love letters, nor delivering them himself and commanding them to somebody else. At the end of the second cycle, he will lose his reputation in the eye of Farfrae and his actions will lead to the death of Lucetta.

A turning point is reached again along with the death of Lucetta and in the third cycle, he places his stepdaughter at the focal point of his life. He starts to imagine a future with her but this dream will be upside down when Newson, the biological father of Elizabeth-Jane, shows up one day and asks for his daughter and this hopeful course will give place to a descending action again. Even if the lie that Henchard has said to Newson thoughtlessly (that Elizabeth-Jane has died) ensures his hold over Elizabeth for a time, Newson comes again and finds the truth in the future as the furmity woman comes from his past and deals a major blow on his life. The result will be that Henchard will lose his stepdaughter and he will leave Casterbridge as a selfbanished outcast. Moreover, he is a "fangless lion" in Hardy's expression (Hardy 2008, 295). He resembles himself to Cain as a self-condemned person by being aware of what he has done while he is leaving Casterbridge and says that: "I - Cain - go alone as I deserve - an outcast and a vagabond. But my punishment is not greater than I can bear!" (Hardy 2008, 291).

In the last two parts of the novel, there is a hope-disaster cycle within itself. We see the return of Henchard to Casterbridge with a goldfinch inside a cage that he has bought as a present to Elizabeth-Jane for apologizing to her. He wants to take shelter in the love and affection of his stepdaughter which is his single remaining love but the lies said and the injustices done once upon a time returns to him like a boomerang. Soon after, Elizabeth-Jane starts to search for Henchard again when she has found the goldfinch which had died of starvation in its cage, she has started to soften towards him but it is too late to improve things between them.

\section{The end of Austerlitz Moment or the Tragic end of Henchard}

Henchard pursues power and status due to his ambitious and passionate nature and ultimately, he has become the mayor of Casterbridge town and a rich tradesman. But this rise has been shaded by the flaws in his character, and then, these have led to his descending. Perhaps, our tragic hero was faced with the results of his "moral flaw" for the first time when furmity woman/Mrs. Goodenough has taunted his own history to Henchard and verbalised the fact that it will not be morally possible for Henchard to judge her. Maybe, he has understood at that moment that his potency and name will be erased. Hardy describes Henchard's end by referring to the word "Austerlitz" which represents Napoleon's twist of luck just before a massive defeat, 
began to reflect what Henchard has gone through and the beginning of his end (Hardy 190, 2008).

Robert Kiely states that there is softness and gentleness in the personality of Henchard despite his rigidity and toughness but he adds that Henchard is incapable of balancing these characteristics, or he simply cannot tolerate the combination of them (Hardy 2008, 200). In the end, Henchard wants to withdraw completely from the stage of this world on which he has not been able to hold and to be out of sight. The testament of Henchard is a remarkable document of a man who wants to make people forget him. As if he wants to disconnect his ties with his family, with society and even the nature, he says as follows:

Elizabeth-Jane Farfrae be not told of my death, or made to grieve on account of me.

$\&$ that I be nor buried in consecrated ground.

$\&$ that no sexton be asked to toll the bell.

$\&$ that nobody is wished to see my dead body.

$\&$ that no mourners walk behind me at my funeral.

$\&$ that no flowers be planted on my grave.

$\&$ that no man remember me (Hardy 2008, 308-309).

\section{Conclusion}

Hardy's narrative use of chance is part of his general philosophical conception based upon the science of the time of a mechanistic universe. Narrative events reveal this philosophical conception in one way, as in another way it is revealed through character traits, presented as predetermined ways of responding to given stimuli, and, in still another way by environmental factors, portrayed as a blend of influences from the historical past entering into the natural and social milieu of the present (Schweik 1966, 15). In the novel, the concept of nature is in many respects traditional as in its concept of man and fate. When nature does enter the novel, it enters as a force obedient and instrumental to a moral order whose rights and claims take priority over man's. This clearly shows the novel's naturalistic and deterministic underlying pattern. Hardy tended to reflect more deliberately upon the implications of Henchard's fall and did so within the framework of his consciously considered view on man's place in a Darwinian world which was identified with the Victorian age (Edwards 1972, 615).

According to some critics like Frederick Karl who investigates the character of Henchard in his essay "The Mayor of Casterbridge: A New Fiction Defined", the destiny or the bad games that the supernatural powers have played have a significant role on the tragic end of Henchard (Hardy 2008, 195). John Paterson, on the other hand, gives the following explanation for Henchard in his essay "The Mayor of Casterbridge as Tragedy", that: "He is a man guilty of having violated a moral order in the world and thus brings upon himself a retribution for his crime" (151). In Virginia Woolf's view, "Henchard is pitied, not against another man, but against something outside himself which is opposed to men of his ambition and power" (Hardy 2008, 146). According to David Cecil, destiny is sometimes allied with the powers of nature in order to beat Henchard (Urgan 2003, 1373). For example, the thing which brings him to bankruptcy is a bad harvest. Henchard regards himself as a victim of a decisive, conscious, and sinister power. But the suffering and tragic end of Henchard has not been induced by fate or secret powers. According to Hornback, Michael Henchard, like Faust, creates his own fate, and cannot escape from it (Hornback 106, 1971). He is the one who has committed these offenses which are preparatory to his sufferings and tragic end. He has auctioned off his wife and 
daughter, he has hidden the real identity of his stepdaughter from her father, he has placed reliance on fake weather fortune tellers, he has delivered the letters of Lucetta to an unreliable man and has led to the death of Lucetta, he has showed vengeful behavior to Farfrae and he has attempted to kill him and has showed cold and reckless behavior towards his stepdaughter. The thing which prepares the end of Michael Henchard is not the dark games of destiny but the dark powers in the personality of Henchard which have devastated him. As pointed out by Hardy, character is indeed fate.

\section{REFERENCES}

Eagleton T. (2013). How to Read Literature. New Haven 2013.

Edwards D. D. (1972). "The Mayor of Casterbridge: An Aeschylean Tragedy”. Studies in the Novel 4/4 (winter, 1972) 608-618.

Gatrell S. (2000). “The Mayor of Casterbridge: The Fate of Michael Henchard's Character”. Ed. J.

Wolfreys, The Mayor of Casterbridge (2000). London.

Hardy T. (2002). Jude the Obscure. Oxford 2002.

Hardy T. (2000). Tess of the d'Urbervilles. Hertfordshire 2000.

Hardy T. (2008). The Mayor of Casterbridge. Oxford 2008.

Hornback B. G. (1971). The Metaphor of Chance. Ohio 1971.

Kiely R. (1968). "Vision and Viewpoint in The Mayor of Casterbridge". Nineteenth-Century Fiction 23/2 (Sep., 1968) 189-200.

Lothe J. (1999). "Variants on genre: The Return of the Native, the Mayor of Casterbridge, the Hand of Ethelberta". Ed. Dale Krummer, The Cambridge Companion to Thomas Hardy (1999). London.

Mill J. S. (2001). On Liberty. Ontario 2001.

Mill J. S. (2007). "The Spirit of the Age". Ed. G. Himmelfarb, The Spirit of the Age: Victorian Essays (2007). New Haven.

Miller J. H. (2000). "The Mayor Casterbridge, the Persistence of the Past, and the Dance of Desire”. Ed. J. Wolfreys, The Mayor of Casterbridge (2000). London.

Millgate M. (2004). Thomas Hardy: A Biography Revisited. Oxford 2004.

Page N. (1999). "Art and Aesthetics". Ed. D. Krummer. The Cambridge Companion to Thomas Hardy (1999). London.

Schweik R. C. (1966). "Character and Fate in Hardy's The Mayor of Casterbridge”. Nineteenth Century Fiction 21/3 (Dec., 1966) 249-262.

Urgan M. (2003). Inngiliz Edebiyat Tarihi. İstanbul 2003.

Wolfreys J. (Ed.) (2000). The Mayor of Casterbridge. London 2000.

Woolf V. (1935). The Common Reader Second Series. Orlando 1935. 